\title{
Gastrointestinal nematodes and anthelmintic resistance in Danish goat herds
}

\author{
Signe A. Holm ${ }^{1,2}$, Camilla R. L. Sörensen ${ }^{1,2}$, Stig M. Thamsborg ${ }^{2}$, and Heidi L. Enemark ${ }^{1, *}$ \\ ${ }^{1}$ Section of Bacteriology, Pathology and Parasitology, National Veterinary Institute, Technical University of Denmark, \\ DK-1870 Frederiksberg C, Denmark \\ 2 Parasitology and Aquatic Diseases, Department of Veterinary Disease Biology, University of Copenhagen, Dyrlægevej 100, \\ DK-1870 Frederiksberg C, Denmark
}

Received 14 February 2014, Accepted 4 July 2014, Published online 31 July 2014

\begin{abstract}
The prevalence of gastrointestinal parasites in Danish goats and the presence of anthelmintic resistance (AR) in 10 selected herds were investigated during April-September 2012. All Danish herds ( $n=137)$ with 10 or more adult goats were invited to participate, and of these 27 herds met the inclusion criterion of more than 10 young kids never treated with anthelmintics. Questionnaire data on management were collected, and faecal samples from 252 kids were analysed by the McMaster technique. From all herds with a mean faecal egg count (FEC) above 300 eggs per $g$ of faeces, pooled samples were stained with peanut agglutinin (PNA) for specific detection of Haemonchus contortus. Strongyle eggs were detected with an individual prevalence of $69 \%$, including Nematodirus battus (3.6\%) and other Nematodirus species (15.0\%). Eimeria spp. were observed in $99.6 \%$ of the kids. H. contortus was found in 11 of $12(92 \%)$ tested herds. Anthelmintics were used in $89 \%$ of the herds with mean treatment frequencies of 0.96 and 0.89 treatments per year for kids and adults, respectively. In 2011 , new animals were introduced into $44 \%$ of the herds of which $25 \%$ practised quarantine anthelmintic treatments. In 10 herds the presence of AR was analysed by egg hatch assay and FEC reduction tests using ivermectin $(0.3 \mathrm{mg} / \mathrm{kg}) \mathrm{or}$ fenbendazole $(10.0 \mathrm{mg} / \mathrm{kg})$. AR against both fenbendazole and ivermectin was detected in seven herds; AR against fenbendazole in one herd, and AR against ivermectin in another herd. In conclusion, resistance to the most commonly used anthelmintics is widespread in larger goat herds throughout Denmark.
\end{abstract}

Key words: Goat, Parasites, Nematode, Parasite control, Herd management, Anthelmintic resistance.

\begin{abstract}
Résumé - Nématodes gastro-intestinaux et résistance aux anthelminthiques chez les troupeaux de chèvres du Danemark. La prévalence des parasites gastro-intestinaux chez les chèvres du Danemark et la présence de résistance aux anthelminthiques (AR) dans 10 troupeaux sélectionnés ont été étudiées d'avril à septembre 2012. Tous les troupeaux danois $(n=137)$ de plus de 10 chèvres adultes ont été invités à participer, et de ces 27 troupeaux 10 remplissait le critère d'inclusion de plus de 10 jeunes n'ayant jamais été traités avec des anthelminthiques. Les données du questionnaire sur la gestion ont été recueillies, et des échantillons fécaux de 252 jeunes ont été analysés par la technique McMaster. De tous les troupeaux avec un nombre moyen d'œufs fécaux (FEC) au-dessus de 300 œufs par gramme de fèces, des échantillons groupés ont été colorées avec l'agglutinine d'arachide (PNA) pour la détection spécifique d'Haemonchus contortus. Les œufs de strongles ont été détectés avec une prévalence individuelle de $69 \%$, dont 3,6\% Nematodirus battus et $15 \%$ d'autres espèces de Nematodirus. Eimeria spp. a été observé chez 99,6\% des jeunes. H. contortus a été trouvée chez 11 des 12 troupeaux testés $(92 \%)$. Les anthelminthiques ont été utilisés dans $89 \%$ des troupeaux avec des fréquences moyennes de traitement de respectivement 0,96 et 0,89 traitement par an pour les jeunes et les adultes. En 2011, de nouveaux animaux ont été introduits dans $44 \%$ des troupeaux dont $25 \%$ pratiquaient des traitements anthelminthiques de quarantaine. Dans 10 troupeaux la présence d'AR a été analysé par des essais d'éclosion des œufs et des tests de réduction de la FEC à l'ivermectine $(0,3 \mathrm{mg} / \mathrm{kg})$ ou au fenbendazole $(10,0 \mathrm{mg} / \mathrm{kg})$. La résistance aux anthelminthiques à la fois au fenbendazole et à l'ivermectine a été détecté dans sept troupeaux ; l'AR au fenbendazole dans un troupeau, et l'AR à l'ivermectine dans un autre troupeau. En conclusion, la résistance aux anthelminthiques les plus couramment utilisés est très répandue dans les grands troupeaux de chèvres dans tout le Danemark.
\end{abstract}

\footnotetext{
*Corresponding author: enhi@vet.dtu.dk

${ }^{2}$ Novel Approaches to the Control of Parasites in Goats and Sheep.

Invited editors: Hervé Hoste, Smaragda Sotiraki, and Michel Alvinerie
}

This is an Open Access article distributed under the terms of the Creative Commons Attribution License (http://creativecommons.org/licenses/by/4.0), which permits unrestricted use, distribution, and reproduction in any medium, provided the original work is properly cited. 


\section{Introduction}

Helminth infections, in particular gastrointestinal nematodes, are found worldwide and are among the most economically important diseases in goats [4, 17, 21, 35, 37]. Control of gastrointestinal nematodes is predominantly based on the use of anthelmintic drugs, but the emergence of anthelmintic resistance (AR) in trichostrongyles in the last three decades represents a major threat to the production of goats [25, 28]. In Denmark resistance against one or more of the broad-spectrum anthelmintics was first reported in Danish goats in 1996 [31], but no comprehensive surveys have been performed since then.

$\mathrm{AR}$ is believed to develop faster in goats than in sheep [7, 47, 51], and although nematodes are generally host-specific, goats and sheep share several species, enabling transmission of resistant nematodes from one species to the other [41, 50]. This aspect makes assessment of AR in goats important, even in countries, such as Denmark, where goats are of minor importance in livestock production. In 2012 there were 23,353 milk, meat or fibre goats in Denmark, distributed among 3,195 herds [26]. The average herd size was 7.2 goats, and $89 \%$ of the herds had $1-9$ goats. Hence, goats are predominantly kept as hobby animals. Haemonchus contortus is a species that has repeatedly been associated with AR [3, 36, 40, 41]. Furthermore, this parasite is increasingly becoming a problem in sheep and goats in temperate areas [30, 33, 43] and has been reported as far north as the Polar Circle [14].

The objectives of the present study were to determine the prevalence of gastrointestinal parasites in Danish goats with a special focus on $H$. contortus, and to assess the occurrence of $\mathrm{AR}$ in selected Danish goat herds.

\section{Materials and methods}

\section{Study design and selection of farms}

In April 2012 an invitation to participate in the prevalence study was submitted to all Danish goat herds registered with 10 or more adult goats, according to the Central Animal Husbandry Register ( $n=137$ herds). In addition, the invitation was posted on the Danish Goat Association's website (www.goat-dgu.dk). Twenty-seven (19.7\%) herds met the inclusion criterion of more than 10 young kids never treated with anthelmintics. Questionnaire data on herd management and practices were collected from all owners $(n=27)$, who also submitted rectally obtained faecal samples from at least 10 kids for initial screening. In a subset of herds $(n=10)$ with a minimum of seven kids and a mean faecal egg count (FEC) $>150$ eggs per $g$ faeces (epg), the presence of AR against ivermectin (IVM) and fenbendazole (FBZ) was analysed using a faecal egg count reduction test (FECRT) and egg hatch assay (EHA). A single herd (\#18) was examined earlier in 2012 [36].

\section{Sampling and laboratory analysis}

\section{Coprological analysis}

Faecal samples were stored in individually labelled plastic bags, and submitted to the laboratory on the day of collection. Faeces was scored for consistency on a scale of $0-5(0=$ hard pellets, $1=$ moist pellets, $2=$ sticky, clumped pellets, $3=$ soft, paste-like with no pellet structure, $4=$ watery diarrhoea, 5 = watery, bloody diarrhoea), vacuum-packed and stored in the dark at room temperature until analysis within one-three days. Helminth eggs and oocysts were quantified using a modified McMaster method [22] with a sensitivity of 5 epg, and eggs were identified to species or genus level [45].

Peanut Agglutinin Staining (PNA) was performed to detect $H$. contortus eggs [16]. From all herds with a mean FEC $\geq 300$ epg, the remaining faeces was pooled, and eggs were isolated, washed and stained with PNA $(0.16 \mathrm{mg} / \mathrm{mL})$ and purified by flotation in Percoll. All or a minimum of 100 strongyle eggs were recorded and the proportion of green fluorescent eggs was estimated using a fluorescence microscope (Leica DMR A 2, 10× objective, band-pass filter 450-490 nm, long-pass filter $515 \mathrm{~nm}$ ).

\section{Faecal egg count reduction test}

A FECRT was performed according to the World Association for the Advancement of Veterinary Parasitology (WAAVP) guidelines [9]. On each farm kids were divided into one-three treatment groups, depending on the herd size, and treated either subcutaneously with IVM $(0.3 \mathrm{mg} / \mathrm{kg})$ (Ivomec $\AA$ Vet., Merial Norden), orally with FBZ $(10.0 \mathrm{mg} / \mathrm{kg})$ (Panacur ${ }^{\circledR}$ Vet., MSD Animal Health) or were left untreated as controls. None of the drugs were registered for use in goats in Denmark but were applied at $1 \frac{1}{2}$ (IVM) and 2 (FBZ) times the recommended sheep dose. All animals were dosed according to individual weight by electronic scales. In farms with $\geq 25$ kids, animals were divided into two treatment groups of 10 kids each (IVM and FBZ) and one control group of 5-10 kids. In farms with 15-24 kids the animals were divided into one treatment group of 10-12 kids (IVM) and one control group of 5-12 kids. In farms with 7-14 kids all animals were treated with IVM. Resampling was done 13-14 days posttreatment. PNA staining was performed in the pretreatment sample from the kid with the highest pretreatment FEC (minimum FEC $\geq 300$ epg).

\section{Egg hatch assay}

An EHA for detection of BZ resistance was performed as described by Coles et al. [9] with modifications [52]. Nematode eggs were isolated from pooled pretreatment samples from each of the 10 herds. A suspension with a known egg concentration was prepared and approximately 100 eggs in $1990 \mu \mathrm{L}$ distilled water were placed in each of 22 wells, on a 24-microwell plate. Ten $\mu \mathrm{L}$ of nine different concentrations of thiabendazole (TBZ) were added to 18 of the wells, each concentration in duplicate. The remaining four wells were used as negative and positive controls. Plates were incubated for $48 \mathrm{~h}$ and then one drop of Lugol's iodine was added to each well. Wells were examined by inverse microscopy and the numbers of strongyle eggs and larvae in each well were recorded.

\section{Questionnaire}

All 27 participating farmers were asked to fill in a questionnaire concerning farm details (e.g. size and composition of goat 
flock), management practices (e.g. management of goats during kidding and grazing seasons, grazing management), drug use (e.g. choice of anthelmintics, treatment strategy) and knowledge about AR. The questionnaire was either answered by e-mail or the farmers were interviewed by telephone or face-to-face.

\section{Data analysis}

Data from the prevalence study, FECRT and questionnaire were summarised by descriptive statistics. FECs of different groups were compared by means of analysis of variance on $\log (x+1)$-transformed counts. The FEC reduction percentage (FECR) was calculated using three different methods:

$$
\text { FECR }=1001-\mathrm{T}_{2} \mathrm{~T}_{1} \times \mathrm{C}_{1} \mathrm{C}_{2}
$$

where $T_{1}$ and $T_{2}$ are the arithmetic means of FECs of the treatment group before and after treatment, and $\mathrm{C}_{1}$ and $\mathrm{C}_{2}$ are the arithmetic means of FECs of the control group at the same time points. According to this method resistance is indicated when FECR $<90 \%$ [39].

$$
\mathrm{FECR}=1001-\mathrm{T}_{2} \mathrm{C}_{2}
$$

A $95 \%$ confidence interval was calculated:

$$
95 \% \mathrm{CI}=1001-\mathrm{T}_{2} \mathrm{C}_{2} \exp \pm 2048 \sqrt{\mathrm{Y}_{2}}
$$

where $T_{2}$ and $C_{2}$ are the arithmetic means of FECs of the treatment group and the control group after treatment. When using this method of calculation, AR is present if the FECR $<95 \%$ and the lower confidence limit is $<90 \%$. If only one of these criteria is present, AR is suspected [9].

$$
\mathrm{FECR}=100\left(1-\mathrm{T}_{2} \mathrm{~T}_{1}\right)
$$

where $T_{1}$ and $T_{2}$ are the arithmetic mean FECs of the treatment group before and after treatment, respectively. This method uses a threshold value of FECR $<95 \%$ to detect AR [34].

In the present study, AR was considered present if the FECR was below the threshold value in one or more of the above-mentioned methods.

In the EHA, the hatching percentage was calculated for each well (larvae/(eggs + larvae $) \times 100)$. The data was analysed in GraphPad Prism Version 5.1 (GraphPad Software, Inc., USA) to determine the concentration required to inhibit hatching of $50 \%$ of strongyle eggs $\left(\mathrm{EC}_{50}\right)$, the $95 \%$ confidence interval, and the coefficient of determination $\left(R^{2}\right)$. According to Coles et al. [9], resistance is declared when the calculated $\mathrm{EC}_{50}$ value is $\geq 0.1 \mu \mathrm{g} / \mathrm{mL}$. Resistance in only a minor nematode species may be declared when $\mathrm{EC}_{50}<0.1 \mu \mathrm{g} \mathrm{TBZ} / \mathrm{mL}$ and concurrent hatching of larvae is seen in $0.3 \mu \mathrm{g} \mathrm{TBZ} / \mathrm{mL}$ [52].

\section{Results}

\section{Prevalences}

Faecal samples were collected from 27 farms during the period 30 April-2 September 2012 (Fig. 1). In each herd 4-12 kids were sampled, totalling 252 individual samples.
None of the goat owners reported clinical signs of parasitism among the sampled kids. The overall prevalence of nematode eggs was $77.0 \%$ and the herd prevalence was $89.0 \%$. The corresponding overall prevalence of strongyle eggs was $69.0 \%$ and the herd prevalence was $81.5 \%$ (Table 1). Nematodirus spp. were found in $15.0 \%$ of the individual samples and $37.0 \%$ of the herds. $N$. battus was detected in four different herds (only identified in a single animal in each of three herds) before June. There were incidental findings of lungworm larvae (species not identified). A large variation was seen in the FECs, mainly due to the $10 \%$ samples in late season (Table 2). PNA staining was performed on samples from 12 farms and $H$. contortus was found in 11 out of these (Table 3).

\section{Faecal egg count reduction test}

In six herds no controls were included in the FECRT due to low numbers of kids, and thus only the McKenna method [34] for FECR was applicable (Table 4). AR against IVM was found in eight of the ten farms. In those farms where all three methods of calculation were applied $(n=4)$, agreement as regards IVM resistance was observed between the results of the different methods. Resistance against FBZ was present in all three farms tested (\#2, 18 and 22), by one or more methods. In farm 2, resistance was only present according to Coles et al. [9], but the reduction percentage was close to the threshold value when using the two other methods. The mean FEC of control groups increased significantly in herd \#22 and decreased in herd \#2 $(p<0.05)$.

\section{Egg hatch assay}

By this method resistance to BZ was detected in all herds except \#3 and \#25 (Table 5). The three herds that tested positive for BZ resistance in the FECRT (\#2, 18 and 22) were also positive in the EHA. The $\mathrm{EC}_{50}$ ranged from 0.069 to $9.803 \times 10^{6} \mu \mathrm{g} \mathrm{TBZ} / \mathrm{mL}$, and the coefficients of determination $\left(R^{2}\right)$ were all above 0.85 . The hatching percentage in the negative controls was above $80 \%$ in all herds, except herd \#18, in which the hatching percentage ranged between 41 and $51 \%$. In herds $\# 3$ and $\# 25, \mathrm{EC}_{50}$ was below $0.1 \mu \mathrm{g} \mathrm{TBZ} / \mathrm{mL}$, but hatching of larvae was seen at a concentration of $0.3 \mu \mathrm{g} / \mathrm{mL}$. When summarising the results from the FECRT and the EHA, seven of the ten herds had AR against both IVM and $\mathrm{BZ}$ in their nematode populations.

\section{Questionnaire}

Questionnaire data were obtained from 27 of the 137 herds which were invited to participate in the study. Herd size ranged from 4 to 500 adult goats, with a mean of 55 goats and a median of 17 goats. Of the 27 herds included in the prevalence study of gastrointestinal nematodes and AR, 15 were hobby herds, of which two were registered as organic and four were zoological gardens. Among the 12 professional herds, 7 were organic, producing either milk, meat or both, and 5 were conventional, producing meat, milk or mohair fibres. Fifty-five percent of the herds had Boer goats, being the dominant breed, followed by "mixed breed" (44\%). The three largest 


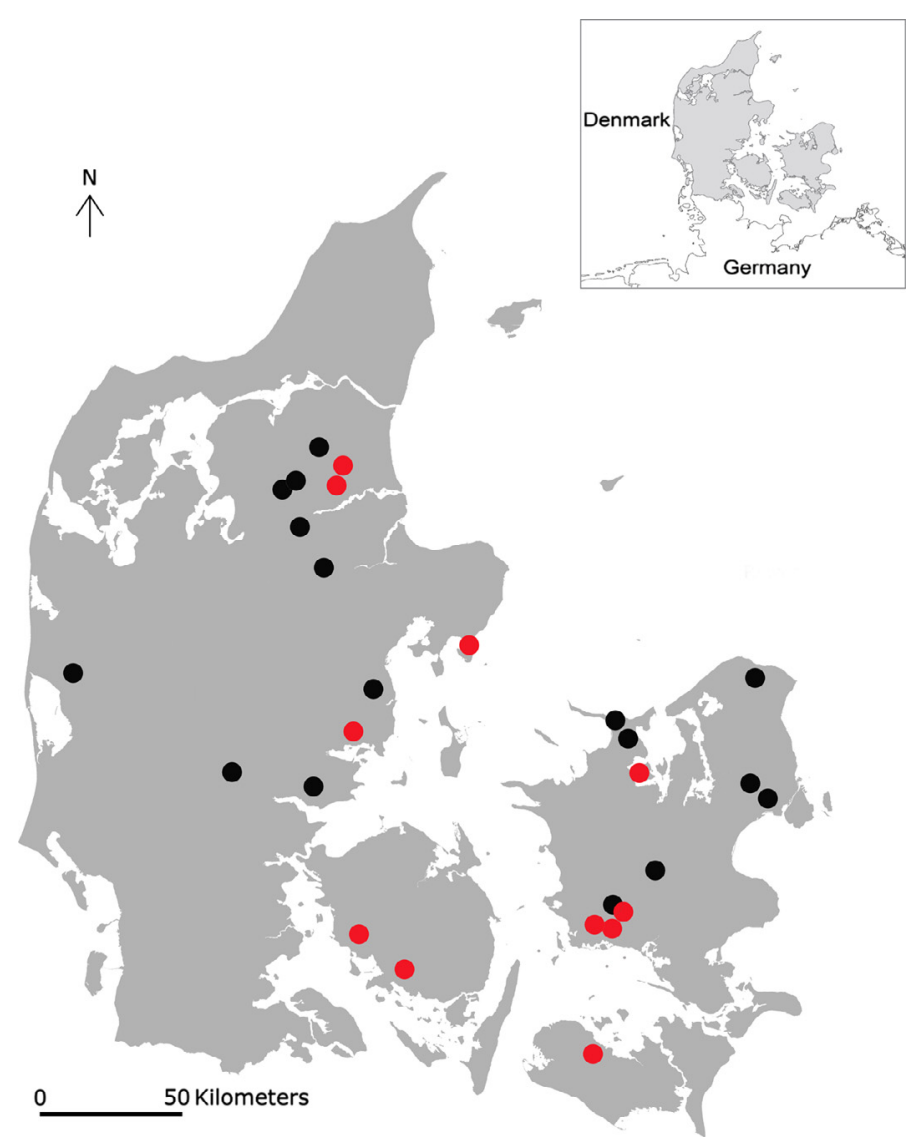

Figure 1. Geographical distribution of herds $(n=27)$ included in the prevalence study of gastrointestinal nematodes of Danish goats, 2012. Red and black dots: participating goat herds. Red dots: goat herds $(n=11)$ that tested positive for Haemonchus contortus.

Table 1. Prevalence of parasite eggs and oocysts in 252 goat kids from 27 Danish farms, 2012.

\begin{tabular}{lcc}
\hline Parasite species & Herd prevalence (95\% CI) & Individual prevalence (95\% CI) \\
\hline Strongyle eggs ${ }^{*}$ & $81.5(63-92)$ & $69.0(63-74)$ \\
Nematodirus battus & $14.8(6-32)$ & $3.6(1-6)$ \\
Other Nematodirus spp. & $37.0(22-56)$ & $15.0(11-20)$ \\
Strongyloides papillosus & $55.6(37-72)$ & $13.1(9-17)$ \\
Trichuris ovis & $63.0(44-78)$ & $33.7(28-40)$ \\
Capillaria longipes & $22.2(12-41)$ & $6.0(3-9)$ \\
Skrjabinema spp. & $18.5(8-37)$ & $4.0(1-6)$ \\
Moniezia expanza & $7.4(2-23)$ & $4.4(2-7)$ \\
Eimeria spp. & $100(88-100)$ & $99.6(99-100)$ \\
\hline
\end{tabular}

95\% CI: 95\% confidence interval. * Strongyle eggs including Nematodirus spp.

Table 2. Characteristics of the individual faecal egg counts (epg) from Danish goat kids in 2012.

\begin{tabular}{lccc}
\hline $\begin{array}{l}\text { Faecal strongyle } \\
\text { egg count }\end{array}$ & $\begin{array}{c}\text { Early summer (30/4-1/7) } \\
(n=232)\end{array}$ & $\begin{array}{c}\text { Late summer }(23 / 8-2 / 9) \\
(n=20)\end{array}$ & $\begin{array}{c}\text { Whole period (30/4-2/9) } \\
(n=252)\end{array}$ \\
\hline Range & $0-810$ & $80-14,340$ & $0-14,340$ \\
Mean $(95 \% \mathrm{CI})$ & $67(51-83)$ & $4213(2598-5828)$ & $396(213-579)$ \\
SD & 125 & 3540 & 1475 \\
Median & 15 & 3190 & 23 \\
\hline
\end{tabular}

95\% CI: 95\% confidence interval. 
Table 3. Detection of Haemonchus contortus eggs by Peanut Agglutinin Staining of pooled faecal samples from kids in 12 Danish goat herds, May-August 2012.

\begin{tabular}{lccc}
\hline Farm number & Fluorescent eggs/total eggs counted & H. contortus $(\%)$ & Detection $+/-$ \\
\hline 2 & $2 / 69$ & 2.9 & + \\
3 & $69 / 110$ & 62.7 & + \\
6 & $28 / 42$ & 66.7 & + \\
9 & $1 / 5$ & n.a. & + \\
10 & $32 / 108$ & 29.6 & + \\
16 & $86 / 109$ & 78.9 & + \\
18 & $90 / 100$ & 90 & + \\
22 & $2 / 83$ & 2.4 & + \\
23 & $0 / 29$ & 0 & + \\
25 & $1 / 106$ & 0.9 & + \\
26 & $108 / 116$ & 93.1 & + \\
27 & $1 / 107$ & 0.9 & + \\
\hline
\end{tabular}

n.a. $=$ not applicable because of low numbers.

Table 4. Faecal egg count reduction percentages in 10 Danish goat herds in 2012, according to three different calculation methods.

\begin{tabular}{|c|c|c|c|c|c|}
\hline Herd & Drug & $n$ & Coles et al. 1992 & Presidente 1985 & McKenna (1990) \\
\hline \multirow[t]{3}{*}{2} & IVM & 10 & $99.7(97.3-100)$ & 99.4 & 99.7 \\
\hline & FBZ & 10 & $92.7(84.9-96.5)^{\mathrm{R}}$ & 90.8 & 95.3 \\
\hline & $\mathrm{C}$ & 10 & - & - & 49.2 \\
\hline 3 & IVM & 7 & - & - & 98.8 \\
\hline 10 & IVM & 13 & - & - & $71.4^{\mathrm{R}}$ \\
\hline 16 & IVM & 13 & - & - & $65.9^{\mathrm{R}}$ \\
\hline \multirow[t]{3}{*}{18} & IVM & 8 & $80.6(62.2-90.1)^{\mathrm{R}}$ & $82.8^{\mathrm{R}}$ & $82.1^{\mathrm{R}}$ \\
\hline & FEN & 8 & $56.3(27.7-73.3)^{\mathrm{R}}$ & $51.1^{\mathrm{R}}$ & $49.1^{\mathrm{R}}$ \\
\hline & C & 8 & - & - & -4.0 \\
\hline \multirow[t]{3}{*}{22} & IVM & 10 & $84.5(68-92.5)^{\mathrm{R}}$ & $83.9^{\mathrm{R}}$ & $49.7^{\mathrm{R}}$ \\
\hline & FEN & 10 & $21.2(-157.5-75.9)^{\mathrm{R}}$ & $-56.2^{\mathrm{R}}$ & $-389.6^{\mathrm{R}}$ \\
\hline & $\mathrm{C}$ & 10 & - & - & -213.5 \\
\hline \multirow[t]{2}{*}{23} & IVM & 10 & $-28.6(-218.7-48.1)^{\mathrm{R}}$ & $55.2^{\mathrm{R}}$ & $45.9^{\mathrm{R}}$ \\
\hline & $\mathrm{C}$ & 10 & - & - & -20.9 \\
\hline 25 & IVM & 7 & - & - & $89.4^{\mathrm{R}}$ \\
\hline 26 & IVM & 10 & - & - & $84.1^{\mathrm{R}}$ \\
\hline 27 & IVM & 8 & - & - & $69^{\mathrm{R}}$ \\
\hline
\end{tabular}

$\mathrm{R}=\mathrm{AR}$ is declared according to the specific calculation method. $\mathrm{IVM}=$ ivermectin, $\mathrm{FBZ}=$ fenbendazole, $\mathrm{C}=$ untreated controls. The $95 \%$ confidence interval is indicated in brackets.

participating herds had a combination of milk-producing breeds (Saanen, Toggenburg and Danish Landrace). A total of 1129 kids were born in the kidding period from January to July with most kiddings during March-April in 19 of the herds (70\%).

The average size of the professional herds in the study was 95 adult goats, whereas the hobby farms had an average size of 23 adult goats. No major differences regarding management were found between hobby and professional goat herds. However, all of the professional herds used pasture rotation, whereas this was only the case in $41 \%$ of the hobby farms. In addition, the professional herds treated more intensively with anthelmintics: $82 \%$ of the professional herds used whole-flock treatments compared with $50 \%$ of the hobby farms; and while hobby farmers treated 0.8 times per year in kids as well as adults, the professional farmers treated 1.2 and 1.0 times per year in kids and adults, respectively.
Table 5. Results from an egg hatch assay in ten Danish goat herds in 2012.

\begin{tabular}{lcc}
\hline Herd & $\mathrm{EC}_{50}(\mu \mathrm{g} \mathrm{TBZ} / \mathrm{ml})$ & $R^{2}$ \\
\hline 2 & $0.11(0.081-0.14)$ & 0.95 \\
3 & $0.087(0.039-0.19)$ & 0.87 \\
10 & $\sim 9.803 \times 10^{6}$ & 0.91 \\
16 & $0.21(0.070-0.66)$ & 0.94 \\
18 & $0.11(0.69-0.18)$ & 0.87 \\
22 & $\sim 0.59$ (very wide) & 0.99 \\
23 & $0.13(0.084-0.19)$ & 0.91 \\
25 & $0.069(0.050-0.095)$ & 0.94 \\
26 & $\sim 28.52$ (very wide) & 0.99 \\
27 & $\sim 67,246$ & 0.85 \\
\hline
\end{tabular}

$\mathrm{EC}_{50}$ above $0.1 \mu \mathrm{g} \mathrm{TBZ} / \mathrm{ml}$ indicates resistance against benzimidazoles. $R^{2}=$ correlation coefficient. The $95 \%$ confidence interval is indicated in brackets. 
Table 6. Number of anthelmintic treatments per year in 27 Danish goat herds, 2012.

\begin{tabular}{lcc}
\hline No. of treatments & \multicolumn{2}{c}{ No. of herds (\%) } \\
\cline { 2 - 3 } & Kids & Adult goats \\
\hline 0 & $9(33)$ & $10(37)$ \\
1 & $11(41)$ & $10(37)$ \\
2 & $6(22)$ & $7(26)$ \\
3 & $1(4)$ & $0(0)$ \\
\hline
\end{tabular}

The mean number of treatments for kids and adult goats, respectively, was 0.96 and 0.89 treatments per year. Treatment frequencies are summarised in Table 6. Three herds (11\%) never used anthelmintic drugs, 6 herds $(22 \%)$ treated without any treatment plan, $7(26 \%)$ treated only at signs of disease, and the remaining $11(41 \%)$ had a predetermined treatment plan, e.g. to treat at kidding or turn-out. In $37 \%$ of the herds anthelmintic treatments were used selectively, whereas the remaining herds treated all animals.

Of the 24 herds that utilised anthelmintics, 15 (63\%) used macrocyclic lactones at their last treatment, $4(17 \%)$ used benzimidazoles, $2(8 \%)$ used other drugs and $3(13 \%)$ did not know which drug they had used. In addition, 15 (63\%) herds had used the same drug repeatedly. As regards anthelmintic efficacy, only one farmer $(4 \%)$ had noticed insufficient anthelmintic efficacy, 6 (25\%) farmers did not know if the anthelmintic had any effect, and 17 (71\%) farmers believed the anthelmintic treatment had the desired effect. All except one of the 27 herds in the study claimed to have a good understanding of AR.

Data concerning deworming of new animals prior to introduction into the flocks were obtained from 24 herds. Of these 12 (50\% corresponding to $44 \%$ of the entire study population) introduced new animals in 2011; and 3 herds (25\%) treated with anthelmintics before the introduction. Among the 12 herds which did not introduce new animals in 2011, 7 stated that they would use quarantine anthelmintic treatment prior to introduction of new goats.

As regards grazing practices, the goats were grazing in all herds except three zoological gardens where the animals only had access to dirt paddocks. Kids and adult goats were grazing together in 22 herds, while they grazed separately in one herd and the kids were kept indoors in the remaining herd. Of the 23 herds with grazing kids, pasture rotation was used in $16(70 \%)$, and $12(52 \%)$ had a specific grazing strategy including: rotating untreated goats to clean pasture $(30 \%)$, “dose and move" (13\%), co-grazing with other animal species (9\%), strip grazing $(4 \%)$ or "other strategies" (17\%).

\section{Discussion}

\section{Parasite fauna}

The prevalences of gastrointestinal parasites found in the present study are similar to previous studies from Norway and Poland [14, 20], with the majority of kids having patent strongyle infection $(69 \%, n=252)$, and practically all kids $(99.6 \%, n=252)$ were infected with Eimeria spp.

Due to generally low FECs PNA was performed in less than half of the participating herds $(n=12)$. Had the samples been collected later the FECs would probably have been substantially higher, since egg excretion generally rises during the grazing season $[6,44]$. H. contortus was found in 11 of the 12 tested herds (92\%). Since only samples with high FECs were stained, the PNA results are subject to selection bias, and the detected herd prevalences may be falsely high. However, recent studies $[5,14]$ confirm a high prevalence even in northern temperate regions. In these areas $H$. contortus primarily over-winters as arrested larvae within the host [30]. Maturation of arrested larvae is expected to peak around kidding, which in this case was primarily in March-April.

Considering the prepatent period of around 2.5-3 weeks [12], it is assumed that the majority of potentially arrested $H$. contortus larvae should have matured and been transmitted to kids in May or later when the samples were collected. Therefore, animals infected with $H$. contortus would be expected to have a FEC above 300 epg at the time of sampling [42], and would consequently be detected in the present study. This means that the detection of $H$. contortus in 11 of the 27 herds (41\%) most likely is a better estimate of the actual prevalence in the study population. Regardless of this, it is concluded that $H$. contortus is a widespread and well-established nematode species in Danish goats.

$N$. battus was only identified in 4 herds and $3.6 \%$ of all individual samples and diarrhoea was not reported by the owners, suggesting that $N$. battus overall is not a major pathogen in Danish goats. Since the majority of samples were collected during the peak period for $N$. battus egg excretion in Northern Europe [46], this prevalence is considered representative for Denmark.

\section{Anthelmintic resistance}

Resistance against one or more anthelmintics was detected in 9 out of 10 herds (90\%). In the FECRT, resistance against BZ was present in all of the three herds tested, and against IVM in eight herds $(80 \%)$. Based on the EHA, resistance against BZ was found in 8 of the 10 herds $(80 \%)$, and thus, dual resistance against both BZ and IVM was present in 7 herds (70\%). A similar occurrence of AR was seen in Danish goat farms in 1996, where the efficacy of BZ, IVM and levamisol was tested using the FECRT and in vitro assays [32]. At that time AR against one or more anthelmintics was detected in 12 of 15 tested farms $(80 \%)$; resistance against BZ was found in 10 out of 15 farms (67\%), and against IVM in 2 out of 2 farms. Due to the low number of farms tested for AR against IVM in 1996, nothing can be concluded concerning the development of resistance against this group of drugs over time. Likewise, it is not possible to assess the national prevalence of $\mathrm{AR}$, since only a few farms were included in both studies. Nevertheless, these studies indicate that AR is widespread and wellestablished among nematodes of Danish goats. 
No anthelmintics are approved for use in goats in Denmark. Thus, IVM and FBZ were applied at $1 \frac{1 / 2}{2}$ and 2 times the dose levels recommended for sheep, which is common practice [1]. The subcutaneous route of administration was chosen for IVM as no oral formulation was registered for use in small ruminants in Denmark. The route of administration is known to significantly affect the pharmacokinetic behaviour of IVM [18, 19, 29]. However, reports concerning the significance of the administration route in goats are conflicting. Pearson and Rutherford [38] described reduced efficacy of IVM injection compared with oral administration at a dose of $0.2 \mathrm{mg} / \mathrm{kg}$, in accordance with results reported by Gopal et al. [19]. However, more recent studies have shown that IVM plasma and tissue concentrations were significantly higher after subcutaneous injection compared with oral administration $[18,29]$. Therefore, we cannot determine to what degree our results were affected by the route of administration

In the present study the various methods used for calculation of FECR generally showed good agreement, and as expected, the largest differences were recorded in farms where there was a large increase or decrease in the FEC in the control group. A statistically significant difference in the FEC was recorded in control groups from herds \#2 and \#22. Most importantly, the methods agreed on the discrimination of resistance and susceptibility in all cases but one (\#2). Regarding the EHA performed in this study, the hatching percentage in negative controls was high $(>80 \%)$, and $\mathrm{R}_{2}$ was above 0.85 in all tests, indicating a good test performance [52]. BZ efficacy was tested in three farms with both the FECRT and EHA and full agreement was seen between the two tests in accordance with several previous studies. [11, 13, 32].

Mixed infections with both susceptible and resistant species may complicate interpretation of FECRT results, especially in cases with the FECR around the threshold level [8, 39]. Egg excretion can range from very high in some fecund species (such as $H$. contortus) to substantially lower in others, resulting in a higher or lower reduction percentage depending on species composition and resistance status. Pre and posttreatment larval cultures enable calculation of the specific FECR for each nematode species, thereby clarifying each species' susceptibility level $[9,39]$. In the present study 4 farms had a FECR in the range $80-95 \%$ and in these cases larval cultures would have been highly relevant. In the 7 herds with dual resistance, we cannot conclude if one or more species were resistant to both drugs, or if one was resistant to IVM and another to BZ. This also requires pre and posttreatment larval cultures.

Similarly, mixed infections can complicate interpretation of EHA results since varying susceptibility between species could result in a range of different $\mathrm{EC}_{50}$. This may explain the wide confidence intervals seen in the present study. Furthermore, the two herds $(\# 3,25)$ with $\mathrm{EC}_{50}$ below $0.1 \mu \mathrm{g} \mathrm{TBZ} / \mathrm{mL}$ in the EHA had larval hatching at the discriminating dose $(0.3 \mu \mathrm{g}$ TBZ $/ \mathrm{mL})$. This indicates that resistant nematode strains were present in all of the ten samples, despite the calculated $\mathrm{EC}_{50}$ suggesting otherwise [52]. It has been suggested to lower the threshold for $\mathrm{EC}_{50}$ to $0.05 \mu \mathrm{g} \mathrm{TBZ} / \mathrm{mL}$ if $H$. contortus is present in the sample [53]. Thus, as $H$. contortus eggs were detected in samples from 9 of 10 herds tested in the EHA a decreased $\mathrm{EC}_{50}$ threshold may have been more appropriate, and would have supported the detection of BZ-resistant strains.

\section{Questionnaire results}

Goats are mainly held as large animal pets in Denmark, and $89 \%$ of Danish goat herds have less than 10 animals [26]. In the present study, a number of large, commercial dairy goat farms were included, and thus, only $56 \%$ of the herds were defined as hobby herds, resulting in a skewed herd size distribution compared with the true distribution. Accordingly, the focus of the present study was on larger goat herds in Denmark where good management (e.g. grazing strategies, quarantine treatment of introduced animals, strategies for anthelmintic treatment) is likely to be of significant importance for the farm economy and animal welfare. When comparing management risk factors associated with anthelmintic resistance between hobby herds and professional herds, only a few differences were observed: treatment intervals were slightly shorter and the whole flock was more widespread in the professional herds. Analysis of correlation between $\mathrm{AR}$ and management risk factors was not possible due to the low number of participating herds in the AR study. A larger sample size would have permitted such an analysis, but as the vast majority of goat herds in Denmark are small, this is difficult to achieve in practice.

Anthelmintic drugs were used in $89 \%$ of the herds, and $75 \%$ of these had a predetermined treatment plan. Examples of such plans were treatments at turn-out, kidding or housing. Treatment at signs of disease was the most common practice, and was used in $29 \%$ of the herds, not necessarily as a deliberate strategy but in several cases as an emergency solution. If selected individual animals are treated, e.g. at signs of disease, this is defined as a targeted selective treatment (TST) [23]. TST is an effective control measure to prevent $\mathrm{AR}$, and despite the selective treatment, productivity in the untreated animals can be maintained $[24,49]$. In the present study a total of $37 \%$ of the herds used TST: $50 \%$ of the hobby herds and $18 \%$ of the professional herds. This relatively restricted use of TST may have been influenced by limited awareness of the benefits of this strategy, fear of disease in untreated animals or the perception that TST is too laborious.

The mean number of treatments per year was 0.96 and 0.89 for kids and adult goats, respectively. In only $26 \%$ of the herds, kids and adults were treated with anthelmintics $\geq 2$ times per year, and the maximum frequency was 3 treatments per year. This is markedly lower than observed in 1996 by Maingi et al. [32], who found that $70 \%$ kids and $90 \%$ adult goats were treated twice or more on a yearly basis, and more than 4 yearly treatments were seen in about $20 \%$ of all herds. This decline in treatment frequency is most likely associated with the introduction of the prescription-only legislation in Denmark in 1996. Generally, the Danish treatment frequencies are low compared with countries with high AR levels, such as South Africa [48], New Zealand and Australia [10, 27], and high treatment frequencies are probably not the major cause of 
AR in Denmark today. A further reduction of the treatment frequency, as recommended to limit AR development [2, 15], will be hard to implement under Danish circumstances, and is not considered realistic.

New animals were introduced into approximately $50 \%$ of the participating herds in 2011; and of these only $25 \%$ treated new animals with anthelmintics prior to introduction into the flocks. The lack of anthelmintic treatment and quarantine measures for goats that are moved between herds or imported from other countries as breeding animals facilitates the spread of nematode species, and is an important factor for dissemination of $\mathrm{AR}[41,50,54]$. Considering the fact that treatment frequencies are fairly low, movement of host animals between flocks is likely to be a major reason for the widespread occurrence of AR in Denmark.

In conclusion, the present study demonstrated $H$. contortus in a large proportion of the tested goat herds; and widespread AR against the most commonly used anthelmintics at the dose levels recommended for goats, and management practices that are known to increase the risk of AR development. Efficiency of other anthelmintic classes, which were not tested in the present study, may still be sufficient against gastrointestinal nematodes in Danish goats. Nevertheless, there are several reasons for concern, and efforts to monitor and control further development of AR are warranted.

Acknowledgements. The study was financed by the Technical University of Denmark. The authors would like to acknowledge veterinary practitioner Inga Stamphøj and the participating goat farmers for encouragement and practical assistance; and the EU COST Action FA0805: CAPARA for scientific support to perform this study.

\section{References}

1. Baynes RE, Payne M, Martin-Jimenez T, Abdullah A, Anderson KL, Webb AI, Craigmil A, Riviere JE. 2000. Extralabel use of ivermectin and moxidectin in food animals. Journal of the American Veterinary Medical Association, 2178, 668-671.

2. Besier RB, Love SCJ. 2003. Anthelmintic resistance in sheep nematodes in Australia: the need for new approaches. Australian Journal of Experimental Agriculture, 43, 1383-1391.

3. Borgsteede FHM, Pekelder JJ, Dercksen DP. 1996. Anthelmintic resistant nematodes in goats in the Netherlands. Veterinary Parasitology, 65, 83-87.

4. Borji H, Azizzadeh M, Kamelli M. 2012. A retroperspective study of abattoir condemnation due to parasitic infections: economic importance in Ahwaz, Southwestern Iran. Journal of Parasitology, 98, 954-957.

5. Burgess CGS, Bartley Y, Redman E, Skuce PJ, Nath M, Whitelaw F, Tait A, Gilleard JS, Jackson F. 2012. A survey of the trichostrongylid nematode species present on UK sheep farms and associated anthelmintic control practices. Veterinary Parasitology, 189, 299-307.

6. Celaya R, Benavides R, García U, Ferreira LMM, Martínez A, Ortega-Mora LM, Osoro K. 2008. Grazing behaviour and performance of lactating suckler cows, ewes and goats on partially improved heathlands. Animal, 2, 1818-1831.
7. Chartier C, Pors I, Hubert J, Rocheteau D, Benoit D, Bernard N. 1998. Prevalence of anthelmintic resistant nematodes in sheep and goats in western France. Small Ruminant Research, 29, 33-41.

8. Coles GC. 2005. Anthelmintic resistance - looking to the future: a UK perspective. Research in Veterinary Science, 78, 99-108.

9. Coles GC, Bauer C, Borgsteede FHM, Geerts S, Klei TR, Taylor MA, Waller PJ. 1992. World Association for the Advancement of Veterinary Parasitology (W.A.A.V.P.) methods for the detection of anthelmintic resistance in nematodes of veterinary importance. Veterinary Parasitology, 44, 35-44.

10. Dash KM, Newman RL, Hall E. 1985. Recommendations to minimize selection for anthelmintic resistance in nematode control programs, in Resistance in nematodes to anthelmintic drugs, 1st edn. Anderson N, Waller P, Editors. CSIRO: Australia. p. 161-169.

11. Demeler J, Kleinschmidt N, Küttler U, Koopmann R, von Samson-Himmelstjerna G. 2012. Evaluation of the egg hatch assay and the larval migration inhibition assay to detect anthelmintic resistance in cattle parasitic nematodes on farms. Parasitology International, 61, 614-618.

12. Devaney JA, Craig TM, Rowe LD. 1992. Resistance to ivermectin by Haemonchus contortus in goats and calves. International Journal for Parasitology, 22, 369-376.

13. Díez-Baños P, Pedreira J, Sánchez-Andrade R, Francisco I, Suárez JL, Díaz P, Panadero R, Arias M, Painceira A, Paz-Silva A, Morrondo P. 2008. Field evaluation for anthelmintic-resistant ovine gastrointestinal nematodes by in vitro and in vivo asssays. Journal of Parasitology, 94, 925-928.

14. Domke AVM, Chartier C, Gjerde B, Leine N, Vatn S, Stuen S. 2013. Prevalence of gastrointestinal helminths, lungworms and liver fluke in sheep and goats in Norway. Veterinary Parasitology, 194, 40-48.

15. Edwards JR, Wroth R, de Chaneet GC, Besier RB, Karlsson J, Morcombe PW, Dalton-Morgan G, Roberts D. 1986. Survey of anthelmintic resistance in Western Australian sheep flocks 2. Relationship with sheep management and parasite control practices. Australian Veterinary Journal, 63, 139-144.

16. Enemark HL, Mohamed A, Ranjitkar S, Juel CD, Thamsborg SM. 2010. Routine diagnosis of Haemonchus contortus using a combination of the McMaster technique, fluorescent peanut agglutinin staining and Percoll flotation, in Proceedings of the XIIth International Congress of Parasitology, Melbourne, Australia, 15-20 August.

17. FAO. 2004. Guidelines resistance management and integrated parasite control in ruminants. Food and Agriculture Organization of the United Nations (FAO): Rome.

18. Gokbulut C, Karademir U, Boyacioglu M. 2007. Comparison of plasma pharmacokinetic profile of ivermectin following administration of subcutaneous injection $\left(\right.$ Baymec $^{\circledR}$ ) and oral tablet $\left(\right.$ Efektin $\left.^{\circledR}\right)$ in goats. Journal of Veterinary Pharmacology and Therapeutics, 30, 489-491.

19. Gopal RM, West DM, Pomroy WE. 2001. The difference in efficacy of ivermectin oral, moxidectin oral and moxidectin injectable formulations against an ivermectin-resistant strain of Trichostrongylus colubriformis in sheep. New Zealand Veterinary Journal, 49, 133-137.

20. Gorski P, Niznikowski R, Strzelec E, Popielarczyk D, Gajewska A, Wedrychowicz H. 2004. Prevalence of protozoan and helminth internal parasite infections in goat and sheep flocks in Poland. Archiv Tierzucht, 47, 43-49. 
21. Gunia M, Mandonnet N, Arquet R, Alexandre G, Gourdine J-L, Naves M, Angeon V, Phocas F. 2013. Economic values of body weight, reproduction and parasite resistance traits for a Creole goat breeding goal. Animal, 7, 22-33.

22. Henriksen SA, Aagaard K. 1976. A simple McMaster and flotation method. Nordisk Veterinaermedicin, 28, 392-397.

23. Hoste H, Torres-Acosta JFJ. 2011. Non chemical control of helminths in ruminants: adapting solutions for changing worms in a changing world. Veterinary Parasitology, 180, 144-154.

24. Hoste H, Chartier C, Lefrileux Y, Goudeau C, Broqua C, Pors I, Bergeaud JP, Dorchies P. 2002. Targeted application of anthelmintics to control trichostrongylosis in dairy goats: results from a 2-year survey in farms. Veterinary Parasitology, 110, $101-108$.

25. Ihler CF. 2010. Anthelmintic resistance. An overview of the situation in the Nordic countries. Acta Veterinaria Scandinavica, 52, 24.

26. Ingvordsen M. 2013. Knowledge of the population structure and husbandry practices of ovine and caprine animals. Ministry of Food, Agriculture and Fisheries, Danish Veterinary and Food Administration: Glostrup, Denmark.

27. Kaminsky R. 2003. Drug resistance in nematodes: a paper tiger or a real problem? Current Opinion in Infectious Diseases, 16, 559-564.

28. Kaplan RM. 2004. Drug resistance in nematodes of veterinary importance: a status report. Trends in Parasitology, 20, 477-481.

29. Lespine A, Alverine M, Sutra J, Pors I, Chartier C. 2005. Influence of the route of administration on efficacy and tissue distribution of ivermectin in goat. Veterinary Parasitology, 128, 251-260

30. Lindqvist A, Ljungström BL, Nilsson O, Waller PJ. 2001. The dynamics, prevalence and impact of nematode infections in organically raised sheep in Sweden. Acta Veterinaria Scandinavica, 42, 377-389.

31. Maingi N, Bjørn H, Thamsborg SM, Bøgh HO, Nansen P. 1996. Anthelmintic resistance in nematode parasites of sheep in Denmark. Small Ruminant Research, 23, 171-181.

32. Maingi N, Bjørn H, Thamsborg SM, Bøgh HO, Nansen P. 1996. A survey of anthelmintic resistance in nematode parasites of goats in Denmark. Veterinary Parasitology, 66, 53-66.

33. Manninen S, Oksanen A. 2010. Haemonchosis in a sheep flock in North Finland. Acta Veterinaria Scandinavica, 52, 19.

34. McKenna PB. 1990. The detection of anthelmintic resistance by the faecal egg count reduction test: an examination of some of the factors affecting performance and interpretation. New Zealand Veterinary Journal, 38, 142-143.

35. Nari A, Hansen JW. 1999. Resistance of ecto- and endoparasites: current and future solutions. 67th General Session, International Committee, OIE, Paris

36. Peña-Espinoza M. 2012. Detection and isolation of antheminticresistant gastrointestinal nematodes of small ruminant in Denmark. A case study in a large organic dairy herd. Master's thesis in Parasitology, University of Copenhagen, Denmark.

37. Perry BD, Randolph TF. 1999. Improving the assessment of the economic impact of parasitic diseases and of their control in production animals. Veterinary Parasitology, 84, 145-168.

38. Pearson AB, Rutherford DM. 1988. Ivermectin injection less effective in goats than oral treatment. Surveillance, 15, 22.

39. Presidente PJA. 1985. Methods for detection of resistance to anthelmintics, in Resistance in nematodes to anthelmintic drugs, 1st edn. Anderson N, Waller P, Editors. CSIRO: Australia. p. $13-27$.

40. Scheuerle MC, Mahling M, Pfister K. 2009. Anthelmintic resistance of Haemonchus contortus in small ruminants in Switzerland and Southern Germany. Wiener klinische Wochenschrift, 121, 46-49.

41. Schnyder M, Torgerson PR, Schönmann M, Kohler L, Hertzberg H. 2005. Multiple anthelmintic resistance in Haemonchus contortus isolated from South African Boer goats in Switzerland. Veterinary Parasitology, 128, 285-290.

42. Silvestre A, Leignel V, Berrag B, Gasnier N, Humbert J, Chartier C, Cabaret J. 2002. Sheep and goat nematode resistance to anthelmintics: pro and cons among breeding management factors. Veterinary Research, 33, 465-480.

43. Thamsborg SM, Søland TM, Vigh-Larsen F. 2001. Klinisk hæmonchose hos făr. Dansk Veterinærtidsskrift, 84, 6-9.

44. Thamsborg SM, Roepstorff A, Monrad J, Grønvold J. 2012. Veterinær parasitologi - Helmintologi for veterinærstuderende, 7th edn. Samfundslitteratur: Copenhagen.

45. Thienpoint D, Rochette F, Vanparijs OFJ. 1986. Diagnosing helminthiasis by coprological examination, 2nd edn. Jansen Research Foundation: Beerse, Belgium.

46. van Dijk J, Morgan ER. 2008. The influence of temperature on the development, hatching and survival of Nematodirus battus larvae. Parasitology, 135, 269-283.

47. van Wyk JA. 2001. Refugia - overlooked as perhaps the most potent factor concerning the development of anthelmintic resistance. Onderstepoort Journal of Veterinary Research, 68, 55-67.

48. van Wyk JA, Stenson MO, van der Merwe JS, Vorster RJ, Viljoen PG. 1999. Anthelmintic resistance in South Africa: surveys indicate an extremely serious situation in sheep and goat farming. Onderstepoort Journal of Veterinary Research, 66, 273-284.

49. van Wyk JA, Hoste H, Kaplan RM, Besier RB. 2006. Targeted selective treatment for worm management - how do we sell rational programs to farmers? Veterinary Parasitology, 139, 336-346.

50. Várady M, Praslicka J, Corba J. 1994. Treatment of multiple resistant field strains of Ostertagia spp., in Cashmere and Angora goats. International Journal of Parasitology, 24, $335-340$.

51. Várady M, Papadopoulos E, Dolinská M, Königová A. 2011. Anthelmintic resistance in parasites of small ruminants: sheep versus goats. Helminthologia, 48, 137-144.

52. von Samson-Himmelstjerna G, Coles GC, Jackson F, Bauer C, Borgsteede F, Cirak VY, Demeler J, Donnan A, Dorby P, Epe C, Harder A, Höglund J, Kaminsky R, Kerboeuf D, Küttler U, Papadopoulos E, Posedi J, Small J, Várady M, Vercruysse J, Wirtherle N. 2009. Standardization of the egg hatch test for the detection of benzimidazole resistance in parasitic nematodes. Parasitology Research, 105, 825-834.

53. von Samson-Himmelstjerna G, Walsh TK, Donnan AA, Carrière $\mathrm{S}$, Jackson F, Skuce PJ, Rohn K, Wolstenholme AJ. 2009. Molecular detection of benzimidazole resistance in Haemonchus contortus using real-time PCR and pyrosequencing. Parasitology, 136, 349-358.

54. Waller PJ. 1997. Nematode parasite control of livestock in the tropics/subtropics: the need for novel approaches. International Journal for Parasitology, 27, 1193-1201. 
Cite this article as: Holm SA, Sörensen CRL, Thamsborg SM \& Enemark HL: Gastrointestinal nematodes and anthelmintic resistance in Danish goat herds. Parasite, 2014, 21, 37.

\section{- PARASTE}

An international open-access, peer-reviewed, online journal publishing high quality papers on all aspects of human and animal parasitology

Reviews, articles and short notes may be submitted. Fields include, but are not limited to: general, medical and veterinary parasitology; morphology, including ultrastructure; parasite systematics, including entomology, acarology, helminthology and protistology, and molecular analyses; molecular biology and biochemistry; immunology of parasitic diseases; host-parasite relationships; ecology and life history of parasites; epidemiology; therapeutics; new diagnostic tools.

All papers in Parasite are published in English. Manuscripts should have a broad interest and must not have been published or submitted elsewhere. No limit is imposed on the length of manuscripts.

Parasite (open-access) continues Parasite (print and online editions, 1994-2012) and Annales de Parasitologie Humaine et Comparée (1923-1993) and is the official journal of the Société Française de Parasitologie. 